\title{
P04-29. HIV-I neutralizing antibodies inhibit plasmacytoid dendritic cells infection
}

\author{
A Lederle*, J Penichon, T Decoville, S Schmidt, C Moog and V Holl
}

Address: Institute of Virology of Strasbourg, Strasbourg, France

* Corresponding author

from AIDS Vaccine 2009

Paris, France. 19-22 October 2009

Published: 22 October 2009

Retrovirology 2009, 6(Suppl 3):P57 doi:10.1 I86/1742-4690-6-S3-P57

This abstract is available from: http://www.retrovirology.com/content/6/S3/P57

(c) 2009 Lederle et al; licensee BioMed Central Ltd.

\section{Background}

Plasmacytoid dendritic cells (PDCs) have been described to link innate and adaptive immunity. Indeed, these cells are able to capture and present antigens, and produce high amounts of cytokines, especially antiviral type I interferons. PDCs are productively infected by HIV in vitro and in vivo, and several studies have shown a decrease in circulating PDCs number that was correlated with an increase of plasma viral load. However, the inhibitory effect of neutralizing antibodies on PDCs infection has not been yet assessed.

\section{Methods}

We first compared primary PDCs purified either by positive selection or by depletion from peripheral blood mononuclear cells of healthy donors. Then, using flow cytometry, the percentage of infected PDCs was determined by the detection of p24-positive BDCA-2+CD123+ cells. We also tested a recently described PDC GEN2.2 cell line for HIV infection.

\section{Results}

After depletion, the subset of PDCs expressing FcyRII corresponding to $30-50 \%$ of total PDCs population was not recovered. This lack of FcyRII+ PDCs hamper the study of Fc $\gamma$ RII mediated inhibitory activity by non-neutralizing inhibitory antibodies. Therefore, PDCs isolated with BDCA-4 positive selection were used to study the inhibition of PDCs infection by the HIV. Preliminary data indicated that neutralizing antibodies were able to efficiently inhibit primary PDCs infection.
We found that PDC GEN2.2 cell line was productively infected by R5 HIV primary isolates. Neutralization study performed on this cell line demonstrated a neutralizing profile similar to primary PDCs.

\section{Conclusion}

Preventing PDCs infection by the induction of efficient HIV-specific antibodies should be one of the goals in HIV vaccine development in order to maintain the PDCs antiviral function during acute infection. 